\title{
THE INFANTILE TYPE OF GAUCHER'S DISEASE
}

\author{
BY
}

\author{
ALAN MONCRIEFF, M.D., M.R.C.P. \\ (From the Hospital for Sick Children, Great Ormond Street, London.)
}

The curious and rare form of splenomegaly which Gaucher first described in 1882 is commonly believed to originate in early childhood, but the majority of the forty to fifty reported cases have sought relief from symptoms arising in adult life. The modern view that the disorder is an inborn error of tissue metabolism would suggest that examples might occur and be discovered accidently in infancy. The object of this paper is to describe a case of Gaucher's splenomagaly where death took place at the age of four months. Curious symptoms pointing to some gross disorder of the nervous system were also present, and this appears to be so constant a feature of the few cases of Gaucher's disease in infancy already recorded as to constitute a distinct clinical picture, differing from Gaucher's disease in adults and presenting many points of interest in diagnosis and pathology. Papers by Oberling and Woringer ${ }^{1}$ in France, and by Dienst ${ }^{2}$ in Germany, contain accounts of the dozen or so cases already recorded, together with a full discussion of the condition and of the literature on this subject.

\section{Case Report.}

For permission to publish the present case I am indebted to Dr. Hugh Thursfield.

Ronald D., was first admitted to the Hospital for Sick.Children, Great Ormond Street, at the age of ten weeks because the mother noticed that he was different from her other children, wóuld not hold his head up, and seemed abnormal.

Parents healthy, not related, not Jewish. There are three other children, a boy aged six years and a boy and girl twins aged three years. All these other children are normal and healthy and have no enlargement of liver or spleen. Dr. Frank Bevan of Hadleigh kindly confirmed this history by examining the children.

The child was admitted for investigation for a few nights only as he was being breast-fed. There was definite head retraction, the child lying in a position of opisthotonos with the arms folded on the chest, the fists being clenched. The pupils were dilated, equal and reacted normally. The optic discs were normal. The only other abrormality noted was that the spleen was very easily felt about two finger's breadth below the costal margin. The Wassermann reaction was negative in the child's blood, the cerebro-spinal fluid was normal and the Wassermann reaction of this was also negative. The mother's blood gave a very slight fixation of the complement, the Kahn reaction being negative. The child was discharged to attend the out-patient department.

Re-admission took place when the child was four months old. The mother had observed that the head retraction was getting worse and that the baby was thinner. On examination the same opisthotonos position was found as before, with brisk tendon-reflexes, flexor plantar responses, absent abdominal reflexes, and a marked squint. The optic discs were normal. The 
cerebro-spinal fluid was again examined: it was not under pressure and was quite normal. The spleen was about the same size as before. The child went downhill rapidly and died in a few days with a terminal diarrhœa. No change was observed in the colour of the child's skin, no blood count was carried out and there was no estimation of the blood cholesterol. The case was diagnosed as one of congenital cerebral defect.

Post-mortem examination.-Body of a much wasted baby, weighing $2 \mathrm{kgrm} .700 \mathrm{grm}$. No gross changes were found in the brain except poorly marked gyri in the occipital region. The intestines showed congestion and catarrh and the mesenteric glands were enlarged. The liver appeared normal. The spleen was much enlarged, weighing $50 \mathrm{grm}$. (This was 1 to 54 of body weight as compared with the normal 1 to 400). It was of a pale brick colour, firm but with no peri-splenitis. No other abnormalities were noticed. Sections were made of the liver, spleen and kidney, and the brain was hardened as a whole. Examination of the histology of the spleen and liver showed the case to be one of Gaucher's disease. Sections made of the brain-tissue were unsatisfactory owing to post-mortem changes in the tissues.

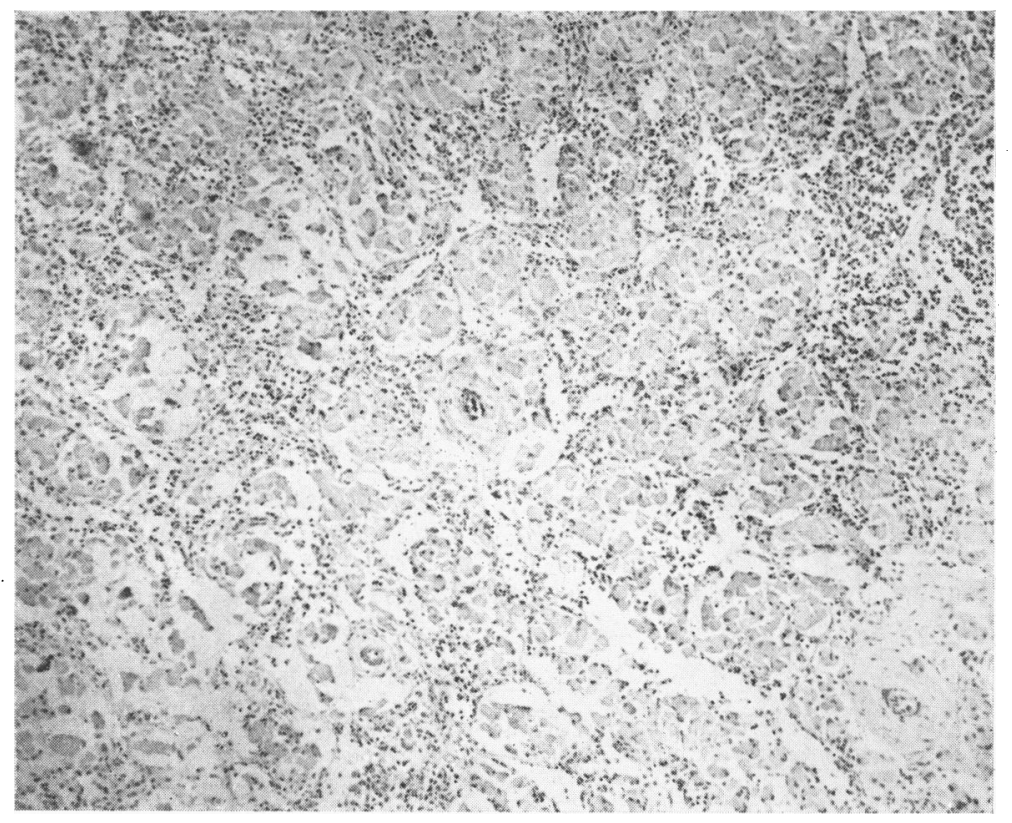

Fra. 1. Section of Spleen $\times 50$. Showing diffuse infiltration by giant cells. (Hæmatoxylin and eosin).

MoRBID HISTOLOGY.-The splenic pulp was almost completely replaced by large cells, averaging about $30 \mu$ in diameter (Figs. 1 and 2). Their protoplasm was clear, appearing faintly granular under high power. The nuclei were small and deeply staining. Groups of cells were found surrounding capillary blood vessels and also around the very occasional Malpighian corpuscles which were found. Staining with Sudan III gave the cells a very faint yellow appearance as described by Bloom ${ }^{3}$. After heating frozien sections to $100^{\circ} \mathrm{C}$., and staining with Sudan III, as described by Graham and Blacklock ${ }^{4}$, much more of the fat stain was taken up by the cells.

The liver was similarly invaded by large cells, and here again groups around the fine capillary vessels were noted. The liver cells stained badly and in areas appeared to be necrotic. No definite increase in fibrous tissue could be detected. The kidney showed some tubular degeneration but no Gaucher cells were seen. 


\section{Discussion.}

The possibilities in clinical diagnosis of an infant presenting the syndrome of (a) wasting without obvious cause, (b) head retraction, opisthotonos and muscular rigidity, and (c) enlargement of the spleen, are limited. Syphilis has to be excluded, and the slight fixation of the complement in the blood of the mother of the present patient can probably be ignored in the absence of any other evidence of this infection. Leukæmia, acholuric jaundice, tuberculosis, tropical conditions and anæmia of the von Jaksch type only cross the mind because of the splenomegaly, and even in the absence of a blood count, tuberculin test, etc., can be excluded in the present case on general grounds. With the histology of the spleen the diagnosis is settled, but the completely accidental nature of this discovery spoilt the chances of a fuller investigation.

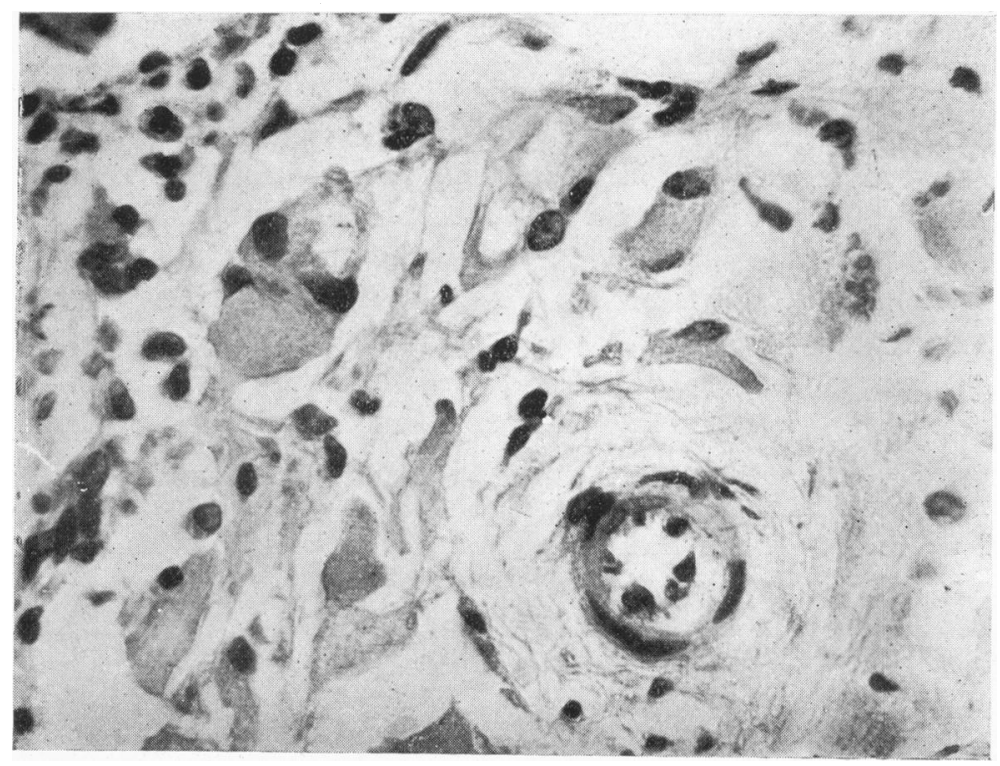

FI(*. 2. Section of Spleen $\times 500$. High power view to show giant cells. (Hamatoxylin and eosin).

The only difficulty which should arise in the clinical diagnosis is to distinguish the infantile type of Gaucher's disease from the closely allied Niemann-Pick disease. This point will be discussed later.

In the paper by Oberling and Woringer mentioned above there is an account of a family in which four out of five children died in the first year of life, apparently from the infantile type of Gaucher's disease as proved by autopsy in two of the cases. The clinical features of these four cases are fully described and the following summary is intended to amplify the necessarily sketchy information about the present case. The occurrence of four cases in one family illustrates the familial nature of the disease, but it is not apparently ever hereditary. These four children were all normal at birth and after a variable period of weeks or months began to waste. Progressive emaciation 
was associated with enlargement of the abdomen due to an increase in the size of the spleen and liver. The curious nervous symptoms of the disease, present in these cases, consisted at first of a striking apathy, the child lying in bed, apparently oblivious of all surroundings, never smiling and interested in nothing, not even in food. Added to this was the positive finding of head retraction and, later, opisthotonos with increased reflexes and the slow development of spasticity in the limbs. Spasm of the glottis occurred towards the end in some cases. Death took place from marasmus or from some intercurrent infection after a variable period from the onset of symptoms, during which irregular bouts of fever were present. Blood counts were normal, there were no hæmorrhages into skin or mucous membranes and no discolouration of the skin was noted. At autopsy typical Gaucher cells, identical with those present in the adult form of the disease, were found in the spleen, liver, bone marrow and lymphatic glands, and only in these situations. The brain showed marked degenerative changes in the cortex.

These French authorities point out that the cases they describe bear resemblances to two other disorders. The rapid onset of nervous symptoms due to cortical degeneration in a previously normal infant is not unlike that in amaurotic familial idiocy. On the other hand the splenic enlargement proved at autopsy to be due to infiltration with giant cells suggests similarities with the Niemann-Pick disorder which must now be described.

Niemann ${ }^{5}$ reported in 1914 an example of what he called Gaucher's disease in a child dying at the age of seventeen months. The same year this was quoted by Rueben ${ }^{6}$ in a paper collecting all the previously published cases of Gaucher's disease occurring in childhood. Subsequent workers, however, discovered differences between this case and true Gaucher's disease and the matter was cleared up in 1926 when Pick $^{7}$ gave a full description of this new form of splenomegaly, now generally known as the Niemann-Pick type. Briefly the clinical features of the eleven cases collected in 1927 by Corcan, Oberling and Dienst $^{8}$ are as follows :-

The children affected are born healthy, are frequently of Jewish parentage and the female sex predominates. Yellow discolouration of the skin, wasting, with enlargement of the liver and spleen, and certain inconstant nervous complications all develop after a few months, leading to a fatal termination before the end of the second year of life. The blood contains a great excess of cholesterol, appearing often quite turbid. The superficial lymphatic glands may become enlarged. Of the eleven cases reported up to 1927 two were mongols and three were examples of amaurotic familial idiocy in addition to the signs and symptoms attributed to the Niemann-Pick disease. At autopsy the lymphatic glands, thymus, and suprarenals may appear bright yellow while giant cells are found not only in the spleen, liver, bone marrow and lymphatic glands, as in Gaucher's disease, but also in the thymus, suprarenal, thyroid and lung in various reported cases. These giant cells stain easily and intensely with the fat stains.

Baty $^{9}$ has recently (1930) described a fresh case of this disorder bringing the total number of cases up to sixteen. 
Corcan and his co-workers urge that there is sufficient difference between this Niemann-Pick type of splenomegaly and the Gaucher type to warrant the two disorders being kept separate. The following Table briefly summarizes the points of difference and similarity :-

Comparison of infantile type of Gaucher's disease and Nienaxy-pick disease.

\begin{tabular}{|c|c|c|}
\hline & Gaucher & Niemann-Pick \\
\hline Age incidence $\quad \ldots$ & $0-2$ years. & $0-2$ years. \\
\hline Familial nature .... & Marked. & Occasional. \\
\hline Race $\quad \ldots \quad \ldots$ & Any. & Mostly Jewish. \\
\hline Splenomegaly $\quad \ldots$. & Present. & Present. \\
\hline Hepatomegaly .... & Present. & Present. \\
\hline Enlargement of glands & Present, but slight. & Present. \\
\hline Yellow skin $\quad \ldots$ & Not present. & Present. \\
\hline Blood count & ?Anæmia and leucopenia. & Normal. \\
\hline Blood cholesterol & Normal. & Raised. \\
\hline Nervous symptoms & May be present. & May be present. \\
\hline Giant cells $\quad \ldots$ & $\begin{array}{l}\text { Present in spleen, liver, bone- } \\
\text { marrow, lymphatic glands. }\end{array}$ & $\begin{array}{l}\text { Present in spleen, liver, bone- } \\
\text { marrow, lymphatic glands, } \\
\text { thymus, adrenal, thyroid and } \\
\text { lung. }\end{array}$ \\
\hline Staining with Sudan III.... & Slight discolouration. & Stain readily. \\
\hline
\end{tabular}

Cases have been recorded, however, in which this difference between these two disorders has not been easy to determine with certitude, and recently Stransky ${ }^{10}$ has pleaded for the use of the term 'giant-celled splenohepatomegaly' to cover both types. He points out that a case described by Dienst $^{2}$ as an example of the Niemann-Pick type on clinical grounds was classified by Hamperl ${ }^{11}$ as Gaucher's disease on histological evidence. In view of the small total number of recorded cases it would seem wise to await further evidence before drawing too hard and fast a line between two disorders which have so much in common. Clinical differentiation may be impossible, although information obtained by splenic puncture or by excision of a lymphatic gland may help.

With the pathological difficulties as to the exact origin of the giant cells, and the biochemical problems of the nature of the material in the giant cells, this paper is not concerned. Papers by Mendlebaum ${ }^{12}$, Bloom ${ }^{3}$, Pick ${ }^{6}$, Graham and Blacklock ${ }^{4}$ deal with these aspects of the matter. It is the clinical picture of a previously healthy baby becoming wasted with splenomegaly and signs of cerebral degeneration to which it is desired to call attention in the hope that other observers may be able to supplement the available evidence as to the exact nature of what appear to be curious examples of congenital defects in metabolism. The relationship between these metabolic errors and the frequently associated disorders of the nervous system opens up an interesting field for speculation in view of the recent work on the blood lipoids in the psychoses (Stenberg ${ }^{13}$ ), but more information is necessary before definite conclusions can be drawn. 


\section{REFERENCES.}

1. Oberling, C., \& Woringer, P., Rev. Franc. de Péd., Paris, 1927, III, 475.

2. Dienst, G., Jahrb.f. Kinderh., Berlin, 1929, CXXIII, 181.

3. Bloom, W., Amer. J. Path., Boston, 1925, I, 595.

4. Graham, S., \& Blacklock, J. W. S., Arch. Dis. Child., Lond., 1927, II, 267.

5. Niemann, A., Jahrb. f. Kinderh., Berlin, 1914, LXXIX, 1.

6. Rueben, M., Amer. J. Dis. Child., Chicago, 1914, VIII, 336.

7. Pick, L., Eng. der Med. u. Kinderh., 1926, XXIX, 519.

8. Corcan, P., Oberling. C. \& Dienst G. Rev. Franc. de Péd., Paris, 1927, III, 789.

9. Baty, J. M., Amer. J. Dis. Child., Chicago, 1930, XXXIX, 573.

10. Stransky, E., Jahrb. f. Kinderh., Berlin, 1930, CXXVI, 204.

11. Hamperl, H., Virchow's Arch.f. path. Anat., Berlin, 1929, CCLXXI, 147.

12. Mendlebaum, F. S., Amer. J. Med. Sci., Philad., 1919, CLVII, 366.

13. Stenberg, S., Psychosis and Blood Lipoids, Stockholm, 1929. 